\title{
Classifying nuisance submerged vegetation depending on ecosystem services
}

\author{
Michiel J. J. M. Verhofstad ${ }^{1}$ Elisabeth S. Bakker ${ }^{1}$
}

Received: 22 February 2017/ Accepted: 17 May 2017/Published online: 5 June 2017

(C) The Author(s) 2017. This article is an open access publication

\begin{abstract}
Throughout the world, mass development of native and non-native submerged macrophytes leads to nuisance problems for humans. However, often neither the type of nuisance nor the characteristics of nuisance vegetation have been uniformly quantified, leaving nuisance vegetation as a largely unsubstantiated qualification. The lack of a consensus about when submerged plants cause nuisance hampers comparative research on the environmental conditions leading to nuisance. Furthermore, defining and evaluating management goals to reduce nuisance caused by submerged plants are not possible when characteristics of the nuisance vegetation remain unquantified. In this study, we performed a literature review and gathered stakeholder information to identify (1) which problems are caused by nuisance submerged macrophytes, (2) which plant characteristics underlie 'nuisance' and (3) and which species cause nuisance. We (4) synthesised this information into a framework to classify submerged vegetation as either 'nuisance' or 'non-nuisance' using a case study to illustrate the principles. We found that most nuisance problems that affect human use of the ecosystem can be grouped into problems for boat traffic, swimming, fishing and hydrological functioning of the system. Additionally, a multitude of ecological effects have also been
\end{abstract}

Handling Editor: Maiko Kagami.

Electronic supplementary material The online version of this article (doi:10.1007/s10201-017-0525-z) contains supplementary material, which is available to authorized users.

Michiel J. J. M. Verhofstad

m.verhofstad@nioo.knaw.nl

1 Department of Aquatic Ecology, Netherlands Institute of Ecology (NIOO-KNAW), Droevendaalsesteeg 10, 6708 PB Wageningen, The Netherlands reported, but these were outside of the scope of this study. Vegetation cover and canopy depth below the water surface are the main determinant characters for nuisance. Therefore, both invasive and native eutrophilic species with a vertical growth strategy are particularly problematic, but other species can also cause nuisance.

Keywords Aquatic plant - Ecosystem service - Invasive · Management · Weed

\section{Introduction}

Freshwater ecosystems fulfil a wide range of ecological functions. They also provide many services for humans, including fresh water supply (e.g. for consumption and irrigation), food supply (e.g. fish), transportation routes, recreation, hydropower and cooling water (Jackson et al. 2001; Aivazidou et al. 2016). Submerged vegetation is considered vital in shallow water ecosystems for performing a number of ecosystem functions that result in enhanced stability of a clear water state in shallow freshwater ecosystems (Carpenter and Lodge 1986; Jeppesen et al. 1997; Van Donk and Van de Bund 2002; Hilt and Gross 2008). Submerged aquatic plants also provide food and habitat for other autotrophs and both vertebrate and invertebrate animal species and can thereby increase freshwater biodiversity (Hargeby et al. 1994; Schriver et al. 1995; Perrow et al. 1999; Mazzeo et al. 2003; Declerck et al. 2005; Bakker et al. 2016). An important target in restoration of degraded aquatic ecosystems is therefore the restoration of stable and diverse aquatic vegetation (Moss et al. 1996; Hilt et al. 2006; Bakker et al. 2013). However, aquatic plants can also be perceived as problematic, in particular when they occur in large numbers (i.e. mass 
development) and interfere with human use of the freshwater ecosystem (Chambers et al. 1999; Hilt et al. 2006; Zehnsdorf et al. 2015).

Clear water and high availability of nutrients in the sediment are thought to facilitate this nuisance growth of macrophytes (Barko and Smart 1986; Bini et al. 1999; Angelstein et al. 2009; Verhofstad et al. 2017). Next to nutrient effects, macrophytes generally also grow faster when temperature and light irradiance increase during the seasons (Kunii 1984; Barrat-Segretain 2004; Bornette and Puijalon 2011). The annual timing of strong macrophyte development often coincides with high anthropogenic use of aquatic ecosystems, as water recreation peaks during the summer months. Nuisance growth of invasive submerged macrophytes, such as Myriophyllum spicatum L., Elodea nuttallii (Planch.) St. John, Egeria densa Planch. and Cabomba caroliniana Gray, have caused many problems for humans worldwide (Smith and Barko 1990; Di Nino et al. 2005; Wilson et al. 2007; Tamayo and Olden 2014). However, these effects are not limited to invasive species (Anderson 2003; Hilt et al. 2006), as any macrophyte species that forms large stands may cause nuisance to one of the freshwater ecosystem functions or services.

Whereas nuisance growth of submerged macrophytes is regularly reported in both scientific and popular media, it is largely undefined what 'nuisance' actually is. What characteristics (e.g. species composition, plant height, plant cover, etc.) does a vegetation have to be a nuisance to humans? To our knowledge, no quantitative method is available to classify whether submerged vegetation creates nuisance for specific ecosystem services or not. In this study, we developed a quantitative approach to identify and classify submerged nuisance aquatic vegetation.

We performed a review of international scientific literature to: (1) identify which problems are caused by nuisance submerged macrophytes and to which ecosystem services these are related; (2) identify macrophyte characteristics that were used to describe the vegetation as 'nuisance;' (3) identify which species have been reported to grow to nuisance levels and whether these are native or non-native species. We used an average Dutch lake as a case study to (4) illustrate our framework classifying a vegetation as either 'nuisance' or 'non-nuisance' using selected plant characteristics and differentiating according to the functions and services the ecosystem fulfils.

\section{Methods}

\section{Literature survey}

We performed a systematic search of the scientific literature to find the most common problems reported with submerged macrophytes, the vegetation characteristics linked to these problems and which species most often cause these problems. To find relevant scientific peer-reviewed papers, the Web of Science search engine was used with the following query:

Query: "TOPIC: (nuisance OR noxious OR problematic) AND [macrophyte* OR (aquatic AND plant*) OR (aquatic AND weed*)]".

This search yielded 346 hits on the 10 February 2017 covering a wide range of aquatic systems and geographic regions (see Electronic Supplementary Material 1). Based on the title and abstract, papers were selected for processing if they contained information on problems caused by submerged freshwater nuisance macrophytes and/or criteria that described macrophytes as nuisance and/or which species were considered a nuisance. Papers describing invasive non-native species were only included in the analysis if the plants were considered a nuisance because of the number at which they occurred, not just because of the fact that they were non-native to that specific site. We found 81 papers that met our criteria from waterways and waterbodies located in North and South America, Europe, Africa and Australia, with the USA being the largest source of scientific studies (ESM 1). Several scientific papers cited local 'grey literature' next to peer-reviewed papers and this local knowledge is therefore indirectly also included in this review. From the selected paper, we extracted (1) problems mentioned that were caused by submerged macrophytes, (2) macrophyte vegetation characteristics linked to nuisance and (3) nuisance macrophyte species reported.

\section{Case study}

Finally, we used the information gathered from the literature review to develop a framework classifying a macrophyte stand as either nuisance or not, depending on local conditions, such as ecosystem service provided and water depth. To define the threshold levels at which submerged macrophytes cause nuisance that our framework requires, the information in the scientific literature was insufficient. For our case study, we therefore gathered additional information concerning the perception of nuisance in the Netherlands from recreational specialists at Alterra (Wageningen University and Research Centre, The Netherlands), The Netherland's Sport Fishing Association (SVN) and the Dutch Water Sports Industry Association (HISWA). We also included information from a survey among 1269 interviewed Dutch recreationalists (for more detailed information, see Goossen et al. 1997). This survey contained information on how importantly people value water quality and aquatic vegetation for engaging in recreational activities such as fishing, swimming and 
boating (Goossen et al. 1997). We used a model shallow (2-m) freshwater ecosystem as our case study, because these ecosystems are very common and typical for The Netherlands and many other countries (e.g. Gulati and Van Donk 2002; Sondergaard et al. 2007). The framework can be tailored to specific waterbodies or waterways by surveying local users about their problems with aquatic vegetation and incorporating corresponding threshold levels of plant abundance into the classification scheme. The thresholds mentioned in our case study (see "Results") are given specifically for the location that is actually used by the community, not for the entire ecosystem. We further assumed homogeneous vegetation distribution in the case study and will discuss spatial heterogeneity and implications for the whole ecosystem in the discussion.

\section{Results}

\section{Recorded problems}

A wide range of plant-induced problems have been reported depending on the use of the aquatic system at hand (Table 1). The main problems can be categorised as problems for boat traffic, fishing, swimming and hydrodynamics. Additional problems that were mentioned less frequently included problems concerning decreased aesthetics, increased sedimentation and altered nutrient cycles (grouped under the category 'Other' in Table 1). Many studies $(n=38)$ also mentioned problems that can be categorised as problems for ecological functioning, especially with regard to non-native species. Because these problems for nature do not necessarily directly impair the anthropogenic functions described, they are outside of the scope of this article and included in the 'Other' category, but we strongly recommend this to be taken up in future research.

\section{Characteristics of nuisance submerged vegetation}

Vegetation that was considered to be a nuisance was mainly characterised by a high plant growth rate, tall height, high coverage, forming (near) monospecific vegetation and/or high biomass (ESM 3). Plant height $(n=24)$ and coverage $(n=45)$ were the most frequently described plant parameters related to nuisance. Most striking was that only 5 of the 78 scientific papers used in this review provided a quantitative measure of nuisance vegetation, namely $>50 \%$ plant cover, $<0.5 \mathrm{~m}$ plant canopy depth or $>0.5 \mathrm{~m}$ plant height under 1-2 $\mathrm{m}$ of water depth (Brandrud and Roelofs 1995; Mataraza et al. 1999; David et al. 2006; Richardson 2008; Alwin et al. 2010). In most papers a specific biomass per square metre, coverage or plant height at which the vegetation was considered as a nuisance was lacking. Several authors did not provide a description of nuisance vegetation but only stated that macrophytes were a nuisance because they 'caused problems'. Together with the description that plants are a nuisance if they are locally very abundant, these descriptions have been categorised as 'Other' (ESM 3), as they cannot easily be attributed to any measurable plant characteristic.

\section{Nuisance species reported}

A diverse group of 33 different submerged macrophyte species were reported as being a nuisance (Table 2). Most frequently mentioned ( $\geq 6$ references) were: M. spicatum, Hydrilla verticillata Royle, Ceratophyllum demersum L.,

Table 1 Summary of the main services provided by the freshwater ecosystem where nuisance aquatic plants cause problems as stated in the scientific literature

\begin{tabular}{|c|c|c|}
\hline $\begin{array}{l}\text { Main functions } \\
\text { categorised }\end{array}$ & Category description & $\begin{array}{l}\text { Number of } \\
\text { references }\end{array}$ \\
\hline Boat traffic & $\begin{array}{l}\text { Impairment of physical movement of a boat or ship through the water by macrophytes, both } \\
\text { recreational and commercial in nature }\end{array}$ & {$[32]$} \\
\hline Fishing & All problems created by macrophytes that hamper recreational or commercial fishing activities & {$[18]$} \\
\hline Swimming & $\begin{array}{l}\text { All problems created by macrophytes that lead to fewer people entering the water for the purpose of } \\
\text { (recreational) swimming }\end{array}$ & {$[17]$} \\
\hline Hydrodynamics & $\begin{array}{l}\text { All problems caused by macrophytes that lead to problematic reduction in water flow or discharge } \\
\text { capacity in waterways, but also congestion of waterbodies and clogging of (industrial) intake pipes }\end{array}$ & [34] \\
\hline $\begin{array}{l}\text { Other (including } \\
\text { 'ecological') }\end{array}$ & $\begin{array}{l}\text { All others, ranging from decreased aesthetics and waterfront property value to increased sedimentation } \\
\text { and altering nutrient cycling of the system } \\
\text { All (biotic) problems created by nuisance macrophytes that concern changes in biodiversity, in the } \\
\text { vegetation, biotic communities, available habitat for other species and damage to the ecosystem in } \\
\text { general. Irrespective of whether this impairs human activities or not }\end{array}$ & [47] \\
\hline
\end{tabular}

See ESM 2 and reference list for actual references 
Table 2 Submerged macrophytes recorded in scientific literature as nuisance species or as dominant species in nuisance vegetation and whether they were non-native in the location at hand

\begin{tabular}{|c|c|c|c|c|}
\hline Species & {$[82]$} & Non-native ${ }_{a}$ & [57] & Native $_{\text {a }}$ \\
\hline Butomus umbellatus L. & {$[1]$} & Madsen et al. (2016) & & \\
\hline $\begin{array}{l}\text { Cabomba caroliniana } \\
\text { Gray }\end{array}$ & {$[3]$} & $\begin{array}{l}\text { Akhurst et al. (2012), Bickel and Schooler (2015 } \\
\text { and Hogsden et al. (2007) }\end{array}$ & {$[2]$} & Cabrera-Walsh et al. (2011) and Nelson et al. (2002) \\
\hline $\begin{array}{l}\text { Ceratophyllum } \\
\text { demersum } \mathrm{L} .\end{array}$ & [3] & $\begin{array}{l}\text { Clayton and Champion (2006), David et al. (2006) } \\
\text { and Wells et al. (2003) }\end{array}$ & [7] & $\begin{array}{l}\text { Charudattan (2001)a, Cruz et al. (2015), Fulmer and } \\
\text { Robinson (2008), Hilt et al. (2006), Nichols } \\
(1991)_{a} \text {, Poirrier et al. (2010) and Zefferman and } \\
\text { Harris (2016) }\end{array}$ \\
\hline $\begin{array}{l}\text { Ceratophyllum } \\
\text { submersum } \mathrm{L} .\end{array}$ & & & {$[1]$} & Hilt et al. (2006) \\
\hline Chara hispida L. & & & {$[1]$} & Hilt et al. (2006) \\
\hline Egeria densa Planch. & {$[8]$} & $\begin{array}{l}\text { Anderson (2003), Clayton and Champion (2006), } \\
\text { David et al. (2006), Madsen (1998), Santos et al. } \\
\text { (2009), Schwarz and Howard-Williams (1993), } \\
\text { Stallings et al. (2015) and Tamayo and Olden } \\
\text { (2014) }\end{array}$ & {$[2]$} & Charudattan (2001) a and Cruz et al. (2015) \\
\hline Egeria najas Planch. & & & {$[2]$} & Charudattan (2001) a and Cruz et al. (2015) \\
\hline $\begin{array}{l}\text { Elodea canadensis } \\
\text { Michaux }\end{array}$ & {$[4]$} & $\begin{array}{l}\text { Abernethy et al. (1996), Aguiar and Ferreira (2013), } \\
\text { Hilt et al. (2006) and Schwarz and Howard- } \\
\text { Williams (1993) }\end{array}$ & {$[2]$} & Nichols and Shaw (1986) and Nichols $(1991)_{a}$ \\
\hline $\begin{array}{l}\text { Elodea nuttallii } \\
\quad \text { (Planch.) St.John }\end{array}$ & {$[1]$} & Hilt et al. (2006) & {$[1]$} & Zefferman and Harris (2016) \\
\hline $\begin{array}{l}\text { Hydrilla verticillata } \\
\text { Royle }\end{array}$ & {$[18]$} & $\begin{array}{l}\text { Anderson (2003), Bacchus and Barile (2005), } \\
\text { Clayton and Champion (2006), Cruz et al. (2015), } \\
\text { David et al. (2006), Evans and Wilkie (2010), } \\
\text { Everitt et al. (1999), Godfrey et al. (1994), Gu } \\
\text { (2006), Madsen (1993, 1998), Michelan et al. } \\
\text { (2014), Nawrocki et al. (2016), Poirrier et al. } \\
\text { (2010), Richardson (2008); Spencer and Ksander } \\
\text { (1999) Stalling et al. (2015) and Yeo and } \\
\text { McHenry (1977) }\end{array}$ & {$[2]$} & Charudattan $(2001)_{\mathrm{a}}$ and Nichols $(1991)_{\mathrm{a}}$ \\
\hline Juncus bulbosus L. & & & {$[5]$} & $\begin{array}{l}\text { Brandrud and Roelofs (1995), Brandrud (2002), } \\
\text { Lucassen et al. (2016), Moe et al. (2013) and } \\
\text { Schneider et al. (2013) }\end{array}$ \\
\hline $\begin{array}{l}\text { Lagarosyphon major } \\
\text { Moss }\end{array}$ & {$[7]$} & $\begin{array}{l}\text { Bickel and Closs (2009), Caffrey et al. (2010), } \\
\text { Clayton and Champion (2006), Hilt et al. (2006), } \\
\text { Mangan and Baars (2013), McKee et al. (2002) } \\
\text { and Schwarz and Howard-Williams (1993) }\end{array}$ & {$[1]$} & Charudattan $(2001)_{\mathrm{a}}$ \\
\hline $\begin{array}{l}\text { Mayaca fluviatiles } \\
\text { Aubl. }\end{array}$ & {$[1]$} & Yakandawala and Dissanayake (2010) & & \\
\hline $\begin{array}{l}\text { Myriophyllum } \\
\text { alterniflorum DC. }\end{array}$ & & & {$[1]$} & Brandrud (2002) \\
\hline $\begin{array}{l}\text { Myriophyllum } \\
\text { aquaticum (Vell.) } \\
\text { Verdc. }\end{array}$ & [7] & $\begin{array}{l}\text { Aguiar and Ferreira (2013), Anderson (2003), } \\
\text { Clayton and Champion (2006), Coetzee et al. } \\
\text { (2011), Hofstra et al. (2006) and Wersal and } \\
\text { Madsen (2011a, b) }\end{array}$ & & \\
\hline $\begin{array}{l}\text { Myriophyllum } \\
\text { heterophyllum } \\
\text { Michx. }\end{array}$ & {$[2]$} & Bailey and Calhoun (2008) and Hilt et al. (2006) & & \\
\hline
\end{tabular}


Table 2 continued

\begin{tabular}{|c|c|c|c|c|}
\hline \multirow{2}{*}{ 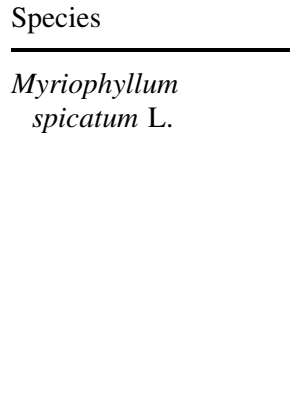 } & \multicolumn{2}{|c|}{ [82] Non-native ${ }_{a}$} & \multicolumn{2}{|c|}{ [57] Native $_{a}$} \\
\hline & {$[19]$} & $\begin{array}{l}\text { Alwin et al. (2010), Anderson (2003), Berger et al. } \\
\text { (2015), Burlakova and Karatayev (2007), Clayton } \\
\text { and Champion (2006), Fulmer and Robinson } \\
\text { (2008), Goodenberger and Klaiber (2016), } \\
\text { Harman et al. (2005), Madsen (1993, 1998), } \\
\text { Newman et al. (1996), Nichols and Shaw (1986), } \\
\text { Poirrier et al. (2010), Reeves et al. (2008), } \\
\text { Richardson (2008), Stalling et al. (2015), Tamayo } \\
\text { and Olden (2014), Trebitz et al. (1993) and } \\
\text { Zefferman and Harris (2016) }\end{array}$ & {$[6]$} & $\begin{array}{l}\text { Abernethy et al. (1996), Cason and Roost (2011), } \\
\text { Charudattan (2001)a, Hilt et al. (2006), Nichols } \\
(1991)_{\mathrm{a}} \text { and Richter and Gross (2013) }\end{array}$ \\
\hline $\begin{array}{l}\text { Myriophyllum } \\
\text { spicatum } \mathrm{L} . \mathrm{x} \\
\text { Myriophyllum } \\
\text { sibiricum Kom. }\end{array}$ & {$[1]$} & Berger et al. (2015) & {$[1]$} & Berger et al. (2015) \\
\hline $\begin{array}{l}\text { Myriophyllum } \\
\text { sibiricum Kom. }\end{array}$ & & & [1] & Fulmer and Robinson (2008) \\
\hline $\begin{array}{l}\text { Myriophyllum } \\
\text { verticillatum } \mathrm{L} .\end{array}$ & & & [1] & Hilt et al. (2006) \\
\hline $\begin{array}{l}\text { Najas flexilis (Willd.) } \\
\text { Rostk. and Schmidt }\end{array}$ & & & {$[1]$} & Jones and Cooke (1984) \\
\hline $\begin{array}{l}\text { Najas guadalupensis } \\
\text { (Spreng.) Magnus }\end{array}$ & & & [2] & Charudattan (2001)a and Poirrier et al. (2010) \\
\hline Najas marina $\mathrm{L}$. & & & {$[2]$} & Fulmer and Robinson (2008) and Hilt et al. (2006) \\
\hline Najas minor All. & {$[1]$} & Stalling et al. (2015) & & \\
\hline $\begin{array}{l}\text { Potamogeton crispus } \\
\text { L. }\end{array}$ & {$[6]$} & $\begin{array}{l}\text { Albright and Ode (2011), Anderson (2003), Fulmer } \\
\text { and Robinson (2008), Nichols and Shaw (1986), } \\
\text { Tamayo and Olden (2014) and Zefferman and } \\
\text { Harris (2016) }\end{array}$ & {$[1]$} & Nichols $(1991)_{\mathrm{a}}$ \\
\hline $\begin{array}{l}\text { Potamogeton foliosus } \\
\text { Raf. }\end{array}$ & & & [1] & Zefferman and Harris (2016) \\
\hline $\begin{array}{l}\text { Potamogeton } \\
\text { gramineus L. }\end{array}$ & & & {$[1]$} & Anderson (2003) \\
\hline Potamogeton lucens L. & & & [1] & Hilt et al. (2006) \\
\hline $\begin{array}{l}\text { Potamogeton } \\
\text { pectinatus } \mathrm{L} .\end{array}$ & & & [7] & $\begin{array}{l}\text { Fulmer and Robinson (2008), Hilt et al. (2006), } \\
\text { Schoonbee (1991)a, Sisneros et al. (1998), Slade } \\
\text { et al. (2008), Sprecher et al. (1998) and Zefferman } \\
\text { and Harris (2016) }\end{array}$ \\
\hline $\begin{array}{l}\text { Potamogeton } \\
\text { perfoliatus } \mathrm{L} .\end{array}$ & & & [2] & Hilt et al. (2006) and Van Nes et al. (2002) \\
\hline $\begin{array}{l}\text { Ranunculus peltatus } \\
\text { Schrank }\end{array}$ & & & {$[1]$} & Garbey et al. (2003) \\
\hline $\begin{array}{l}\text { Ranunculus } \\
\text { penicillatus subsp. } \\
\text { pseudofluitans } \\
\text { (Syme) Webster }\end{array}$ & & & [1] & Garbey et al. (2003) \\
\hline $\begin{array}{l}\text { Zannichellia palustris } \\
\text { L. }\end{array}$ & & & {$[1]$} & Zefferman and Harris (2016) \\
\hline
\end{tabular}

Numbers between square brackets indicate number of cases. For the geographical location of the studies, see ESM 1

a: Species in references annotated with ' a' cannot be assigned as native or non-native (e.g. because the reference was a review article). They are always placed in the 'native' column (13 cases) 
A. Nuisance

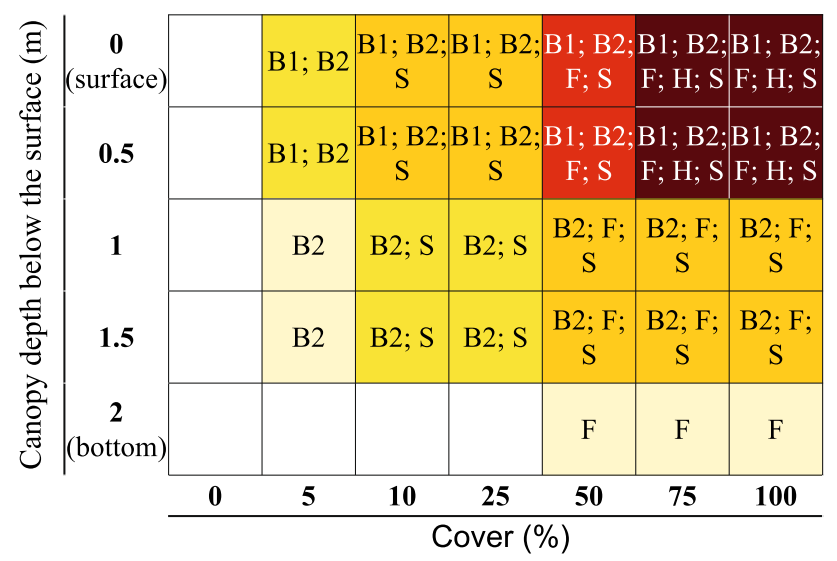

B. Services

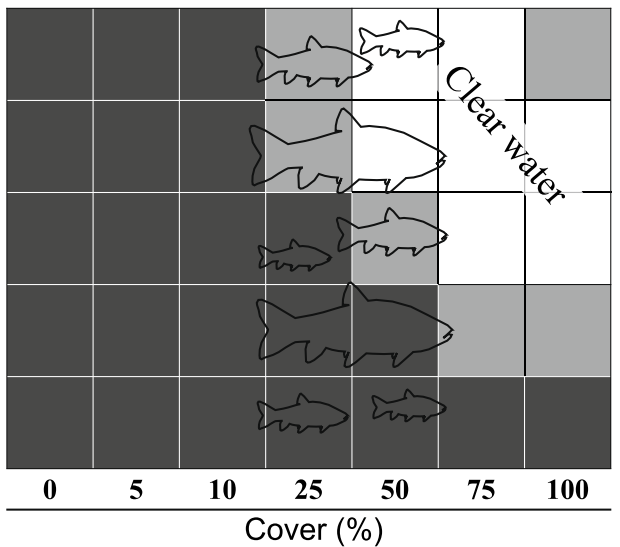

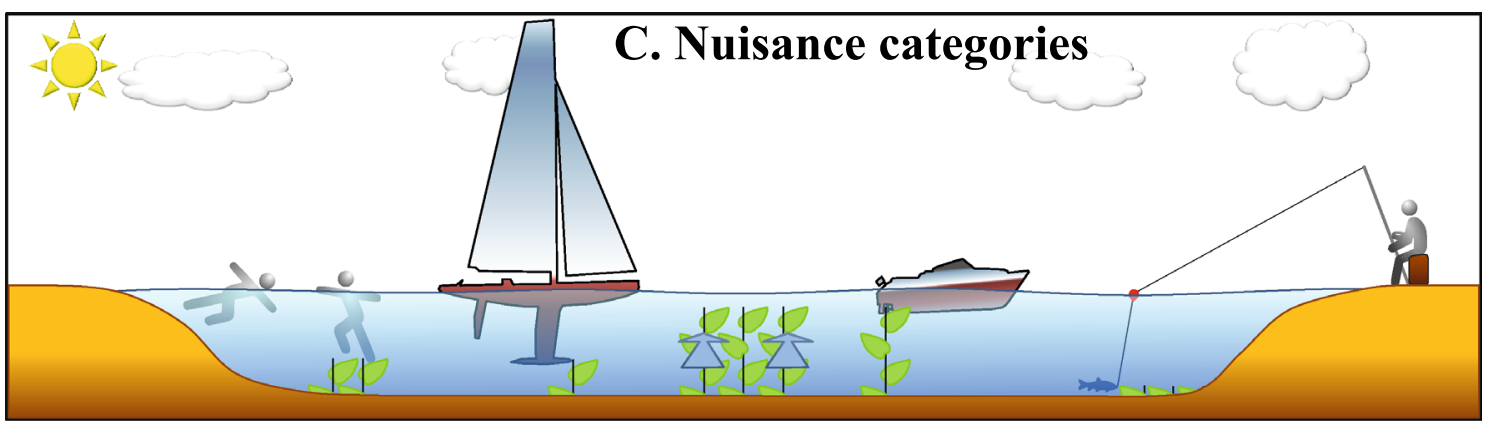

S: Swimming B2: Large boats H: Hydrodynamics B1: Small boats $\quad$ F: Fishing (i.e. flow)

Fig. 1 a Case study (water depth $=2 \mathrm{~m}$ ) classification of nuisance macrophyte vegetation by plant canopy depth and plant cover depending on ecosystem services provided by the aquatic system, as proposed by the authors for sites in the ecosystem where the functions are performed. Letters indicate that macrophytes are classified as nuisance for each anthropogenic function: B1 (small recreational boats); $B 2$ (large recreational boats); $F$ (fishing); $S$ (swimming); $H$ (hydrodynamics, i.e. water flow in this case). For a graphical representation, see c. Darker (red) fills indicate more services are impaired by macrophytes. b Probability of maintaining two important

\section{E. densa, Lagarosiphon major Moss, Elodea canadensis} Michaux and Potamogeton pectinatus L. M. spicatum, which were reported most often as being a nuisance species, namely in 25 papers. Several macrophyte species have been reported to be a nuisance in both their native and introduced range (7), while others have mainly been reported as nuisance in either their native (17) or introduced ranges (8) (Table 2).

\section{Determining thresholds: case study}

Following the literature (Washington et al. 1992; ESM 3), we propose that classifying nuisance for human use can best be done by combining both plant canopy depth and plant cover as factors (Fig. 1a). With plant cover we indicate the per cent surface area occupied by macrophytes. Plant canopy depth is the difference between water depth ecosystem services (i.e. clear water and fish populations) in shallow aquatic systems considering the total area of the ecosystem. Lighter fills are generally considered more desirable for the stability of the clear water state. The school of fish indicates the plant cover that is suggested as optimal for fish populations. See "Discussion": "Aquatic plant problems versus services' for more details on how these thresholds were chosen. Fish size has no informative meaning. c Graphical representation of the ecosystem services impaired by submerged plant growth, as reported in a

and plant height, i.e. the thickness of the water column above the vegetation canopy. Submerged macrophytes become a direct nuisance for humans when too many shoots physically touch humans (swimming) or manmade objects (boating and fishing) in both waterbodies and waterways or when they obstruct flow in waterways (impede hydrodynamics). To separate nuisance from nonnuisance vegetation based on the two selected plant parameters, it is essential to first identify at what canopy depth and cover submerged macrophytes will pose a problem for the different types of ecosystem services the aquatic ecosystem may deliver (Murphy 1988). The first step in determining the threshold levels above which submerged macrophytes will be considered a nuisance for specific ecosystem services is thus to identify which services are provided by the ecosystem. To determine these nuisance threshold levels, we suggest surveying the local 
users about how many plants are perceived to impair the ecosystem service at hand. Because perception is very subjective and can be exaggerated, we suggest incorporating the available scientific knowledge on actual problems caused by submerged plant growth where possible. Additionally, quantitative metrics about the users of the ecosystem services can also help to remove perception bias. With quantitative metrics we mean for example the size and draught of the recreational boats used for the ecosystem service: boating. In the following sections, we will illustrate in more detail how to determine the threshold values for all ecosystem services mentioned, using The Netherlands as an example.

\section{Thresholds for boat traffic}

In many freshwater ecosystems a large portion of boat traffic will consist of recreational vehicles. Aquatic macrophytes will become a nuisance when they entangle the propellers of motorboats or hit and wrap around the keel or swards of sailing boats. This results in reduced recreational use of the location (Eiswerth et al. 2000; Dodds et al. 2009). Threshold levels thus depend on the draught of the boats present at a location. For our case study, a cover of as low as 5\% within the navigational area is suggested to cause nuisance for boating if macrophytes grow tall enough to come in contact with the boat (HISWA, personal communication). A survey of nearly the entire Dutch recreational fleet (for details, see WaterrecreatieAdvies 2005) and advice provided by HISWA made it possible to roughly group the majority of vessels into two groups and estimate the draught of the most common recreational boats. The report by WaterrecreatieAdvies (2005) described the number of vessels, type and estimated size of boats present in the Dutch recreational fleet. The first group consists mainly of small boats (up to $1-1.25-\mathrm{m}$ draughts) stored on land, but still frequently used. The second group consists of vessels that are mainly docked at marinas or water sports associations and mainly consist of larger boats with larger draughts up until around $2 \mathrm{~m}$. Because almost all boats will draw at least $0.5 \mathrm{~m}$ of water, all recreational boat traffic will have problems if macrophytes are present between 0 and $0.5 \mathrm{~m}$ below the water surface and cover at least $5 \%$. The majority of the Dutch fleet will encounter problems when macrophyte canopy depth lies between 0 and $1 \mathrm{~m}$ deep. A smaller portion of the fleet in our case study (roughly half to two-third) still encounters problems when the macrophyte canopy depth is between 1 and $2 \mathrm{~m}$ below the water surface. When macrophytes deeper than $2 \mathrm{~m}$ are present only very few vessels will encounter problems, even when the macrophyte cover is high.

\section{Thresholds for fishing}

Lines getting entangled in vegetation pose a major problem of submerged macrophytes for fishermen. Catch is lost and/ or lines can break, leading to loss of gear and pollution of the environment. High vegetation density results in reduced recreational use of affected sites (Eiswerth et al. 2000). According to The Netherland's Sport Fishing Association $(\mathrm{SVN})$ the recreational fishermen regard a macrophyte cover of between 10 and $40 \%$ as optimal for fishing in our case study (Peters and Van Emmerik 2013). In the USA, a similar cover of between 20 and $40 \%$ has been suggested as optimal for a stable fish population (AERF 2005). A cover of 50\% and higher is considered a nuisance (SVN personal communication). Depending on the species of fish targeted, different fishing methods will be applied. When fishing for bottom-dwelling species macrophytes of only a few centimetres tall can already cause problems. When fishing for species that prefer the open water macrophytes can grow much taller before becoming a nuisance. As a waterbody or waterway will most likely be used to fish for both types of fish, a macrophyte cover of $50 \%$ or higher is classified as a nuisance for fishing independent of canopy depth in our case study. Macrophytes can also hamper fishing by causing problems for boat navigation, but these problems are described under the section concerning 'thresholds for boat traffic'.

\section{Thresholds for swimming}

When macrophytes reach very high densities they can become dangerous for swimmers, the shoots can entangle arms and legs leading to dangerous situations. However, even when macrophyte densities are not dangerously high, many people are still deterred from swimming by submerged macrophytes touching their skin. At what cover and canopy depth people will find submerged macrophytes a nuisance will depend on personality and culture. Recreational swimmers in The Netherlands generally do not mind the presence of 'some vegetation in the water' (Goossen et al. 1997). Taking the average length of humans into account, plants present at $2 \mathrm{~m}$ or deeper will almost never be considered a nuisance in our case study. Plants present at $1.5-0 \mathrm{~m}$ depth might be considered a nuisance as people are likely to be able to touch them while swimming. As the presence of some vegetation will still be considered tolerable and not deter people to swim in waterbodies or waterways on a warm day, the cover at which macrophytes will be considered a nuisance has been arbitrarily set at $10 \%$ in our case study, but should be adjusted to reflect local views. 


\section{Thresholds for hydrodynamics}

One of the main functions of waterways in particular, but also of hydropower reservoirs, is the transport of water (either to drain or to supply). Everything present in the water column will create resistance to the water flow and thereby reduce discharge capacity of the system. Massive development of submerged macrophytes can thereby severely reduce the amount of water that can flow through the system in a given time, increasing the chance of flooding (Bal et al. 2011). Several authors examined the hydraulic resistance of submerged macrophytes and the effects on water flow; however no clear threshold level for cover and canopy depth above which the vegetation will cause a significant problem was reported. The nuisance threshold will depend on the characteristics of the macrophyte species (e.g. flexibility), minimum flow capacity requirement of the water system at a specific time, pattern of the vegetation in the aquatic system and the bottom morphology of the waterway (Green 2005; Vereecken et al. 2006; Bal et al. 2011). Modelling indicated increased flow resistance at vegetation blockage of a channel of more than $50 \%$ (for details and model conditions, see: Green 2005). Empirically, more than $42 \%$ PVI (i.e. water volume inhabited by plants) did increase flow resistance under experimental conditions (Vereecken et al. 2006). However, up to $60 \%$ of vegetation in an artificial channel showed a flow resistance (Vereecken et al. 2006) that would not necessarily lead to flooding problems in rivers (Bal et al. 2011). Summarising, a PVI of 50\% appears to be a good starting point threshold level at above which macrophytes will cause hydrological problems in our case study. It should be noted that the spatial pattern of the vegetation influences the resistance it will inflict on water flow (Green 2005; Vereecken et al. 2006; Bal et al. 2011). Furthermore, plant fragments can also easily clog pipes and pumps used for cooling water or irrigation (Richardson 2008). However, no general threshold value can be given as this will depend on the local specification of the pump (e.g. size and power), diameter of the pipes, mesh size of debris screens, etc.

\section{Compiling the framework}

Different ecosystems may provide different ecosystem services, the first step in classifying nuisance should thus be to identify which services are provided by the ecosystem at hand. Here we will show how to develop a classification scheme for a model shallow lake in The Netherlands that provides all the ecosystem services discussed above. We combine all these threshold values for cover and canopy depth from the separate ecosystem services and create one classification scheme for nuisance submerged macrophytes for our case study. We chose an ecosystem with a water depth of $2 \mathrm{~m}$ as an illustrative case study, but the same method can be applied in waterbodies and waterways with different depths. Threshold nuisance submerged macrophyte levels of cover and canopy depth for boat traffic, fishing and swimming in the case study can be used in the classification scheme without having to be transformed using our site-specific water depth (B, F, S in Fig. 1a, respectively). Because our classification framework requires both canopy depth and cover as main factors, the threshold PVI value of the hydrodynamics category needs to be converted to these two parameters. The PVI can be calculated by dividing submerged macrophyte volume by water volume. Submerged macrophyte volume can be calculated by multiplying plant height with plant cover. To calculate the macrophyte canopy depth and cover at the threshold level PVI for nuisance we thus need to know the water depth. A threshold PVI of more than $50 \%$ is reached at any combination of $75-100 \%$ plant cover and canopy depth of $0.5 \mathrm{~m}$ below the water surface or less in our schematic ( $\mathrm{H}$ in Fig. 1a). Even though the PVI is easy to calculate in theory, determining the PVI of plants under field conditions can be difficult. Variation in shoot densities within a plant patch can make it difficult to accurately assess true cover. Furthermore, water flow can reduce plant height by pushing the shoots downwards making actual height estimates challenging. Overall, submerged plants will not cause problems in our case study when they lie on the bottom and cover less than $50 \%$ of the surface or when they cover less than $5 \%$ of the area, irrespective of canopy depth at that site (Fig. 1a).

\section{Discussion}

\section{Nuisance problems, vegetation characteristics and nuisance species}

A wide variety of problems for human use and ecological functioning of ecosystems caused by submerged macrophytes has been reported. Four main categories could be identified for human-related problems: problems for boat traffic, fishing, swimming and hydrodynamics. Each category (i.e. ecosystem service provided) has a unique threshold level at which plants become a nuisance. Threshold levels for nuisance of measurable vegetation parameters were largely absent in the scientific literature, but vegetation cover and canopy depth below the surface were most often used to describe nuisance. In our classification framework, we therefore combined plant cover with plant canopy depth as the main factors determining if a macrophyte stand will cause nuisance for a specific ecosystem service, or not. 
Dozens of submerged macrophyte species were recorded in the scientific literature as causing problems for humans. Most of these species are known to possess a vertical growth strategy and some are notorious for forming surface canopies (e.g. E. densa, Elodea spp., H. verticillata, L. major, M. spicatum, Potamogeton pectinatus and $P$. crispus). Species with these characteristics likely pose the biggest risk. Many of these species also require this vertical growth to reach the water surface in order to flower (see Duarte and Kalff 1990). However, several other species reported to cause nuisance are not readily associated with this type of growth (e.g. Charophytes and Najas flexilis, Wingfield et al. 2006; Table 2). The list of species that can cause nuisance presented here is not exhaustive. Many more species have the potential to become a nuisance when environmental conditions allow for excessive growth. Environmental conditions enabling nuisance growth will most likely vary between species (reviews by Lacoul and Freedman 2006; Bornette and Puijalon 2011).

\section{Applying and improving the nuisance classification framework}

\section{Integrating ecosystem morphology}

We used an ecosystem with a depth of $2 \mathrm{~m}$ as an illustrative case study to convert nuisance threshold PVI values into canopy depth and cover. Because of the shallow depth of these ecosystems, light can often reach the bottom enabling submerged macrophyte growth throughout the ecosystem (e.g. Trebitz et al. 1993; Hilt et al. 2006; Pot and Ter Heerdt 2014). Therefore, these shallow ecosystems may be particularly vulnerable for problems concerning nuisance growth of macrophytes (e.g. Burlakova and Karatayev 2007; Alwin et al. 2010). The classification scheme can easily be adapted for waterbodies and waterways with different depths, as the nuisance threshold value itself remains unchanged. However, the deeper a system becomes, the less likely macrophytes are to reach the threshold value for canopy depth, and thus nuisance, because of the physiological limitations of the plants (Lacoul and Freedman 2006).

\section{Integrating macrophyte species characteristics}

Many submerged macrophyte species have been a nuisance, but several species have been reported more often than others. This could be due to specific species' traits such as the ability to quickly grow tall and form surface canopies or show strong lateral expansion, thereby increasing the likelihood of becoming a nuisance, although species without the same traits can also become a nuisance, but perhaps not as often. Including information on specific plant species on potentially relevant plant traits such as toughness (Bociag et al. 2009), flexibility or maximum shoot density could thus further improve the classification framework by including species-specific threshold levels at which macrophytes are considered a nuisance. The impact species-specific traits can have on the nuisance threshold levels can, for example, be included in the framework by adding a species specific correction factor (i.e. ranging from 0 to 1 ) to the general threshold levels. Here, a very mechanically strong species will have a factor of 1 and very weak species will have a lower correction factor.

The present study focussed on submerged freshwater macrophytes, but similar problems concerning nuisance growth of species with different growth forms, such as floating species, have been reported (e.g. Spencer et al. 2006; Arthur et al. 2007; Wu and Wu 2007; O'Sullivan et al. 2010; Perna et al. 2012). In contrast to submerged species, floating leaved species such as Eichhornia crassipes or Trapa natans, but also emergent species such as Ludwigia spp. or Phragmites australis, may be even more likely to cause nuisance problems, because they inherently grow on or through the water surface and thus have a high chance of causing nuisance problems to ecosystem users. Due to the general nature of the nuisance problems and the vegetation characteristics used to classify nuisance, our proposed classification can easily be adapted and extended to include macrophyte species with different growth forms. For example, the plant canopy depth factor will not be useful in the classification framework when applied to floating leaved species (i.e. canopy depth is always 0). However, the cover threshold values of the framework are still valid.

\section{Integrating varying ecosystem services and local perception}

While performing the review, it became apparent that it was impossible to create one threshold value of cover and depth above which aquatic plants will be perceived as a nuisance (e.g. Suren 2009) and our classification will thus benefit from including site-specific information on perception of nuisance. For example, Chambers et al. (1999) summarised that the tolerable upper limit of aquatic plant cover, before complaints are filed and management is triggered, lies between less than $1 \%$ and up to $50 \%$ in Canada. This is in agreement with our case study and shows the large range this threshold can have because of local views and usage requirements of the different assigned ecosystem services. We therefore propose that managers and scientists tailor the framework to the ecosystem at hand by (1) identifying the ecosystem services provided by the ecosystem, (2) determining at what per cent cover and canopy depth the plants will impair each 
of the services provided and (3) assessing whether a corresponding reduction in macrophytes is beneficial for the ecosystem or whether it will lead to conflicts among different services with different plant requirements. A large reduction in submerged macrophyte PVI can potentially have detrimental effects on the ecosystem and the ecosystem services provided.

\section{Aquatic plant problems versus services}

Eliminating nuisance submerged vegetation via management may reduce anthropogenic problems for usage of aquatic systems, but many ecosystem services also rely on the ecosystem functions performed by submerged plants, such as maintaining good water quality and healthy fish populations.

Water quality is very important for recreation (Goossen et al. 1997). Fishing, hunting and bird watching also benefit from submerged plant presence, as these plants may attract waterfowl and increase fish stocks (Noordhuis et al. 2002; AERF 2005; O'Hare et al. 2007; Hansson et al. 2010; Peters and Van Emmerik 2013). Removing too many plants can increase the risk of complete loss of submerged vegetation, development of potentially toxic phytoplankton blooms and thus indirectly jeopardise several human uses of the system (Van Nes et al. 2002; Dodds et al. 2009; Kuiper et al. 2017). However, it is unknown how much plant volume is actually needed for a stable clear water ecosystem (Hilt et al. 2006), because the minimum PVI required will differ per ecosystem and depends on factors including: macrophyte traits; nutrient status of the system; presence, type and abundance of fish; and many more (e.g. Søndergaard and Moss 1997; Hilt and Gross 2008; Bakker et al. 2010). Most likely, PVI in temperate freshwater ecosystems should be higher than $15-30 \%$ to maintain a clear and macrophyte-dominated lake (Søndergaard and Moss 1997; Hilt et al. 2006; Nakamura et al. 2008; Sondergaard et al. 2010), but no threshold PVI level was found for waterways. However, a too high PVI of (close to) $100 \%$ can be detrimental for water quality and ecosystem stability, especially when extensive surface canopies are formed. This can result in very low oxygen concentrations near the bottom in the macrophyte stands (Schwarz and Howard-Williams 1993; Miranda and Hodges 2000; Nakamura et al. 2008).

Next to increasing water clarity, submerged vegetation may additionally have a direct and positive impact on one ecosystem service in particular: fishing, likely because the aquatic plants provide food and habitat for many animals, including fish (Carpenter and Lodge 1986), thereby maintaining a stable fish population. Similar to the provision of clear water, no single optimal value of macrophyte PVI for the fish populations was found in the scientific literature.
Macrophyte cover values in the region of $20-60 \%$ have been suggested to be beneficial for fish populations and fishing (Dibble et al. 1996; AERF 2005; Peeters and Van Emmerik 2013). Very high macrophyte densities can result in low oxygen levels and potentially decrease fish populations (Miranda and Hodges 2000). However, this optimal macrophyte cover may not be true for all fish species or aquatic ecosystems (e.g. stratified temperate lakes: Cheruvelil et al. 2005).

Using these suggested PVI and cover values and using our case study ecosystem with a depth of $2 \mathrm{~m}$ as an example, we developed an additional classification scheme showing when too few or too many plants are present in the lake to maintain the two beneficial ecosystem functions discussed (Fig. 1b). Because these threshold values may vary among different ecosystems (Murphy 1988), we advise performing an ecosystem analysis to tailor the values to specific ecosystems.

\section{Spatial heterogeneity}

It now becomes apparent that it is nearly impossible to use an entire shallow lake for the anthropogenic functions discussed while keeping clear water in the ecosystem in the plant-dominated state (see Fig. 1a versus b). This seems only possible if abiotic factors prevent nuisance submerged plant growth all together (e.g. very low nutrient concentrations, high flow velocity or rocky substrates). However, this does not mean that ecosystem managers will have to choose for either (1) an aquatic system in the plant dominated state, but without the possibility of unhampered anthropogenic functions, or (2) a system without any submerged macrophytes and a high chance of poor water quality. It merely stresses the importance of incorporating whole ecosystem functioning and spatial aspects into the management plans for selected human uses of the system (Finlay and Vogt 2016). This is especially true because it is not always possible to assign the different ecosystem functions and services to different aquatic ecosystems.

So far, we have not addressed the spatial heterogeneity of aquatic plants and ecosystem services, but many ecosystem services do not require the whole aquatic ecosystem. Swimming, for example, will mainly be restricted to the area surrounding a beach or an easy access point and will remain close to the shoreline. So, the canopy depth and cover of the vegetation needed to prevent nuisance to the swimmers will only apply locally. Similar arguments can be made for boating and fishing. Consequently, management only needs to take place in areas where macrophyte growth actually causes problems (Finlay and Vogt 2016). Other parts of the ecosystem can still be occupied by submerged macrophytes to maintain their functions for the ecosystem as a whole. Furthermore, 
submerged macrophytes themselves often show a patchy distribution in aquatic ecosystems and activities could thus be allocated towards the sites with fewer plants. If the underlying causes of nuisance submerged macrophyte growth cannot be removed, harvesting nuisance aquatic plants may be a suitable management method to temporarily alleviate local problems (Quilliam et al. 2015; Finlay and Vogt 2016; Hussner et al. 2017). An additional advantage of this method is that it removes nutrients that are incorporated in the plant biomass from the ecosystem, which can be used for a wide variety of useful applications, for example as agricultural fertiliser or food for cattle (Edwards 1980; Quilliam et al. 2015).

\section{Conclusions}

Our classification framework shows that the number of plants considered to be a nuisance depends on the services the ecosystem fulfils. The framework combines vegetation cover and canopy depth as the main factors for the quantitative classification of nuisance versus non-nuisance submerged vegetation. The classification framework can be used to define and evaluate lake and waterway management goals, as it is possible to quantitatively define nuisance and desirable vegetation dimensions, depending on the ecosystem service provided. The use of our classification framework in future research also enables researchers to compare individual studies where nuisance macrophyte growth is reported as well as review the underlying causes of nuisance growth.

Whereas submerged macrophytes can become nuisance vegetation for multiple ecosystem services, we stress that submerged macrophytes simultaneously provide essential services in shallow freshwater ecosystem, for example, maintaining stable clear water conditions. Therefore, we suggest that lake management should strive for spatial differentiation of human activities and plant growth if the underlying mechanisms enabling nuisance cannot be removed.

Acknowledgements We wish to thank Martin Goossen (Alterra) for providing a survey amongst Dutch recreationalists and Willie van Emmerik (SVN) for providing insight and data on the wishes of recreational fishermen concerning macrophyte cover and canopy depth. We would also like to thank Geert Dijks (HISWA) for his input into the problems for boating. Finally, we also wish to thank the reviewers for their constructive comments on an earlier version of this manuscript. This is publication 6307 of The Netherlands Institute of Ecology (NIOO-KNAW).

Open Access This article is distributed under the terms of the Creative Commons Attribution 4.0 International License (http://crea tivecommons.org/licenses/by/4.0/), which permits unrestricted use, distribution, and reproduction in any medium, provided you give appropriate credit to the original author(s) and the source, provide a link to the Creative Commons license, and indicate if changes were made.

\section{References}

Abernethy VJ, Sabbatini MR, Murphy KJ (1996) Response of Elodea canadensis Michx and Myriophyllum spicatum L to shade, cutting and competition in experimental culture. Hydrobiologia 340:219-224

AERF: Aquatic Ecosystem Restoration Foundation (2005) Best management practices handbook for aquatic plant management in support of fish and wildlife habitat. Aquatic Ecosystem Restoration Foundation, Marietta, GA. USA. http://www.michi gan.gov/documents/deq/wrd-ANC-BMP-FishWildlife_477685_ 7.pdf. Accessed 30 May 2016

Aguiar FCF, Ferreira MT (2013) Plant invasions in the rivers of the Iberian Peninsula, south-western Europe: a review. Plant Biosyst 147:1107-1119

Aivazidou E, Tsolakis N, Iakovou E, Vlachos D (2016) The emerging role of water footprint in supply chain management: a critical literature synthesis and a hierarchical decision-making framework. J Clean Prod 137:1018-1037

Akhurst DJ, Jones GB, Clark M, Reichelt-Brushett A (2012) Effects of carp, gambusia, and Australian bass on water quality in a subtropical freshwater reservoir. Lake Reserv Manage 28:212-223

Albright TP, Ode DJ (2011) Monitoring the dynamics of an invasive emergent macrophyte community using operational remote sensing data. Hydrobiologia 661:469-474

Alwin TG, Fox MG, Cheruvelill KS (2010) Estimating lake-wide watermilfoil weevil (Euhrychiopsis lecontei) density: the roles of quadrat size, sample size, and effort. J Aquat Plant Manage 48:96-102

Anderson LWJ (2003) A review of aquatic weed biology and management research conducted by the United States Department of Agriculture-Agricultural Research Service. Pest Manag Sci 59:801-813

Angelstein S, Wolfram C, Rahn K, Kiwel U, Frimel S, Merbach I, Schubert H (2009) The influence of different sediment nutrient contents on growth and competition of Elodea nuttallii and Myriophyllum spicatum in nutrient-poor waters. Fundam Appl Limnol 175:49-57

Arthur GD, Stirk WA, Novak O, Hekera P, van Staden J (2007) Occurrence of nutrients and plant hormones (cytokinins and IAA) in the water fern Salvinia molesta during growth and composting. Environ Exp Bot 61:137-144

Bacchus ST, Barile PJ (2005) Discriminating sources and flowpaths of anthropogenic nitrogen discharges to Florida springs, streams and lakes. Environ Eng Geosci 11:347-369

Bailey JE, Calhoun AJK (2008) Comparison of three physical management techniques for controlling variable-leaf milfoil in Maine lakes. J Aquat Plant Manage 46:163-167

Bakker ES, Van Donk E, Declerck SAJ, Helmsing NR, Hidding B, Nolet BA (2010) Effect of macrophyte community composition and nutrient enrichment on plant biomass and algal blooms. Basic Appl Ecol 11:432-439

Bakker ES, Sarneel JM, Gulati RD, Liu ZW, van Donk E (2013) Restoring macrophyte diversity in shallow temperate lakes: biotic versus abiotic constraints. Hydrobiologia 710:23-37

Bakker ES, Wood KA, Pages JF, Veen GF, Christianen MJA, Santamaria L, Nolet BA, Hilt S (2016) Herbivory on freshwater and marine macrophytes: a review and perspective. Aquat Bot $135: 18-36$ 
Bal K, Struyf E, Vereecken H, Viaene P, De Doncker L, de Deckere E, Mostaert F, Meire P (2011) How do macrophyte distribution patterns affect hydraulic resistances? Ecol Eng 37:529-533

Barko JW, Smart RM (1986) Sediment-related mechanisms of growth limitation in submersed macrophytes. Ecology 67:1328-1340

Barrat-Segretain MH (2004) Growth of Elodea canadensis and Elodea nuttallii in monocultures and mixture under different light and nutrient conditions. Arch Hydrobiol 161:133-144

Berger ST, Netherland MD, MacDonald GE (2015) Laboratory documentation of multiple-herbicide tolerance to fluridone, norflurazon, and topramazone in a hybrid watermilfoil (Myriophyllum spicatum $\mathrm{x} M$. sibiricum) population. Weed Sci 63:235-241

Bickel TO, Closs GP (2009) Impact of partial removal of the invasive macrophyte Lagarosiphon major (Hydrocharitaceae) on invertebrates and fish. River Res Appl 25:734-744

Bickel TO, Schooler SS (2015) Effect of water quality and season on the population dynamics of Cabomba caroliniana in subtropical Queensland, Australia. Aquat Bot 123:64-71

Bini LM, Thomaz SM, Murphy KJ, Camargo AFM (1999) Aquatic macrophyte distribution in relation to water and sediment conditions in the Itaipu Reservoir, Brazil. Hydrobiologia 415:147-154

Bociag K, Galka A, Lazarewicz T, Szmeja J (2009) Mechanical strength of stems in aquatic macrophytes. Acta Soc Bot Pol 78:181-187

Bornette G, Puijalon S (2011) Response of aquatic plants to abiotic factors: a review. Aquat Sci 73:1-14

Brandrud TE (2002) Effects of liming on aquatic macrophytes, with emphasis on Scandinavia. Aquat Bot 73:395-404

Brandrud TE, Roelofs JGM (1995) Enhanced growth of the macrophyte Juncus bulbosus in S Norwegian limed lakes. A regional survey. Water Air Soil Poll 85:913-918

Burlakova LE, Karatayev AY (2007) The effect of invasive macrophytes and water level fluctuations on unionids in Texas impoundments. Hydrobiologia 586:291-302

Cabrera-Walsh G, Schooler S, Julien M (2011) Biology and preliminary host range of Hydrotimetes natans Kolbe (Coleoptera: Curculionidae), a natural enemy candidate for biological control of Cabomba caroliniana Gray (Cabombaceae) in Australia. Aust J Entomol 50:200-206

Caffrey JM, Millane M, Evers S, Moran H, Butler M (2010) A novel approach to aquatic weed control and habitat restoration using biodegradable jute matting. Aquat Invasions 5:123-129

Carpenter SR, Lodge DM (1986) Effects of submersed macrophytes on ecosystem processes. Aquat Bot 26:341-370

Cason C, Roost BA (2011) Species selectivity of granular 2,4-D herbicide when used to control Eurasian watermilfoil (Myriophyllum spicatum) in Wisconsin lakes. Invas Plant Sci Mana 4:251-259

Chambers PA, DeWreede RE, Irlandi EA, Vandermeulen H (1999) Management issues in aquatic macrophyte ecology: a Canadian perspective. Can J Bot 77:471-487

Charudattan R (2001) Are we on top of aquatic weeds? Weed problems, control options, and challenges. In: DPPGFLUSA Univ Florida (ed) International Symposium on the World's Worst Weeds. British Crop Protection Council, Brighton, pp 43-68

Cheruvelil KS, Nate NA, Soranno PA, Bremigan MT (2005) Lack of a unimodal relationship between fish growth and macrophyte cover in 45 north temperate lakes. Arch Hydrobiol 164:193-215

Clayton J, Champion P (2006) Risk assessment method for submerged weeds in New Zealand hydroelectric lakes. Hydrobiologia 570:183-188

Coetzee JA, Hill MP, Byrne MJ, Bownes A (2011) A review of the biological control programmes on Eichhornia crassipes
(C.Mart.) Solms (Pontederiaceae), Salvinia molesta DSMitch. (Salviniaceae), Pistia stratiotes L. (Araceae), Myriophyllum aquaticum (Vell.) Verdc. (Haloragaceae) and Azolla filiculoides Lam. (Azollaceae) in South Africa. Afr Entomol 19:451-468

Cruz C, Silva AF, Venturini FP, Garlich N, Pitelli R, Pitelli RA (2015) Food preference and consumption of aquatic macrophytes submerged by snail Pomacea canaliculata. Planta Daninha 33:433-439

David N, Greenfield BK, Siemering GS (2006) Evaluating impacts of Lake Maid (TM) plant control. J Aquat Plant Manage 44:60-66

Declerck S, Vandekerkhove J, Johansson L, Muylaert K, CondePorcuna JM, Van der Gucht K, Perez-Martinez C, Lauridsen T, Schwenk K, Zwart G, Rommens W, Lopez-Ramos J, Jeppesen E, Vyverman W, Brendonck L, De Meester L (2005) Multi-group biodiversity in shallow lakes along gradients of phosphorus and water plant cover. Ecology 86:1905-1915

Di Nino F, Thiebaut G, Muller S (2005) Response of Elodea nuttallii (Planch.) H. St. John to manual harvesting in the North-East of France. Hydrobiologia 551:147-157

Dibble ED, Killgore KJ, Harrel SL (1996) Assessment of fish-plant interactions. Am Fish S S 16:357-372

Dodds WK, Bouska WW, Eitzmann JL, Pilger TJ, Pitts KL, Riley AJ, Schloesser JT, Thornbrugh DJ (2009) Eutrophication of US freshwaters: analysis of potential economic damages. Environ Sci Technol 43:12-19

Duarte CM, Kalff J (1990) Biomass density and the relationship between submerged macrophyte biomass and plant-growth form. Hydrobiologia 196:17-23

Edwards P (1980) Food potential of aquatic macrophytes. ICLARM Studies and Reviews 5:51 pp. International Center for Living Aquatic Resources Management, Manila

Eiswerth ME, Donaldson SG, Johnson WS (2000) Potential environmental impacts and economic damages of Eurasian watermilfoil (Myriophyllum spicatum) in western Nevada and northeastern California. Weed Technol 14:511-518

Evans JM, Wilkie AC (2010) Life cycle assessment of nutrient remediation and bioenergy production potential from the harvest of hydrilla (Hydrilla verticillata). J Environ Manage 91:2626-2631

Everitt JH, Yang C, Escobar DE, Webster CF, Lonard RI, Davis MR (1999) Using remote sensing and spatial information technologies to detect and map two aquatic macrophytes. J Aquat Plant Manage 37:71-80

Finlay K, Vogt RJ (2016) An ecosystem management framework to maintain water quality in a macrophyte-dominated, productive, shallow reservoir. Hydrobiologia 776:111-123

Fulmer JE, Robinson AT (2008) Aquatic plant species distributions and associations in Arizona's reservoirs. J Aquat Plant Manage 46:100-106

Garbey C, Thiebaut G, Muller S (2003) Impact of manual spring harvesting on the regrowth of a spreading aquatic plant: Ranunculus peltatus Schrank. Arch Hydrobiol 156:271-286

Godfrey KE, Anderson LWJ, Perry SD, Dechoretz N (1994) Overwintering and establishment potential of Bagous affinis (Coleoptera, Curculionidae) on Hydrilla verticillata (Hydrocharitaceae) in northern California. Fla Entomol 77:221-230

Goodenberger JS, Klaiber HA (2016) Evading invasives: how Eurasian watermilfoil affects the development of lake properties. Ecol Econ 127:173-184

Goossen CM, Langers F, Lous JFA (1997) Indicatoren voor recreatieve kwaliteiten in het landelijk gebied. DLO-Staring Centrum, Wageningen, p 132 (in Dutch)

Green JC (2005) Modelling flow resistance in vegetated streams: review and development of new theory. Hydrol Process 19:1245-1259 
Gu BH (2006) Environmental conditions and phosphorus removal in Florida lakes and wetlands inhabited by Hydrilla verticillata (Royle): implications for invasive species management. Biol Invasions 8:1569-1578

Gulati RD, van Donk E (2002) Lakes in the Netherlands, their origin, eutrophication and restoration: state-of-the-art review. Hydrobiologia 478:73-106

Hansson LA, Nicolle A, Bronmark C, Hargeby A, Lindstrom A, Andersson G (2010) Waterfowl, macrophytes, and the clear water state of shallow lakes. Hydrobiologia 646:101-109

Hargeby A, Andersson G, Blindow I, Johansson S (1994) Trophic web structure in a shallow eutrophic lake during a dominance shift from phytoplankton to submerged macrophytes. Hydrobiologia 279:83-90

Harman WN, Hingula LP, MacNamara CE (2005) Does long-term macrophyte management in lakes affect biotic richness and diversity? J Aquat Plant Manage 43:57-64

Hilt S, Gross EM (2008) Can allelopathically active submerged macrophytes stabilise clear-water states in shallow lakes? Basic Appl Ecol 9:422-432

Hilt S, Gross EM, Hupfer M, Morscheid H, Mahlmann J, Melzer A, Poltz J, Sandrock S, Scharf EM, Schneider S, de Weyer KV (2006) Restoration of submerged vegetation in shallow eutrophic lakes - a guideline and state of the art in Germany. Limnologica 36:155-171

Hofstra DE, Champion PD, Dugdale TM (2006) Herbicide trials for the control of parrotsfeather. J Aquat Plant Manage 44:13-18

Hogsden KL, Sager EPS, Hutchinson TC (2007) The impacts of the non-native macrophyte Cabomba caroliniana on littoral biota of Kasshabog Lake, Ontario. J Great Lakes Res 33:497-504

Hussner A, Stiers I, Verhofstad MJJM, Bakker ES, Grutters BMC, Haury J, van Valkenburg J, Brundu G, Newman J, Clayton JS, Anderson LWJ, Hofstra D (2017) Management and control methods of invasive alien freshwater aquatic plants: a review. Aquat Bot 136:112-137

Jackson RB, Carpenter SR, Dahm CN, McKnight DM, Naiman RJ, Postel SL, Running SW (2001) Water in a changing world. Ecol Appl 11:1027-1045

Jeppesen E, Jensen JP, Sondergaard M, Lauridsen T, Pedersen LJ, Jensen L (1997) Top-down control in freshwater lakes: the role of nutrient state, submerged macrophytes and water depth. Hydrobiologia 342:151-164

Jones GB, Cooke GD (1984) Control of nuisance aquatic plants with burlap screen. Ohio J Sci 84:248-251

Kuiper JJ, Verhofstad MJJM, Louwers ELM, Bakker ES, Brederveld RJ, van Gerven LPA, Janssen ABG, de Klein JJM, Mooij WM (2017) Mowing submerged macrophytes in shallow lakes with alternative stable states: battling the good guys? Environ Manage 59:619-634

Kunii H (1984) Seasonal growth and profile structure development of Elodea nuttallii (Planch) St John in pond Ojaga-Ike, Japan. Aquat Bot 18:239-247

Lacoul P, Freedman B (2006) Environmental influences on aquatic plants in freshwater ecosystems. Environ Rev 14:89-136

Lucassen E, Roelofs JGM, Schneider SC, Smolders AJP (2016) Longterm effects of liming in Norwegian softwater lakes: the rise and fall of bulbous rush (Juncus bulbosus) and decline of isoetid vegetation. Freshw Biol 61:769-782

Madsen JD (1993) Biomass techniques for monitoring and assessing control of aquatic vegetation. Lake Reserv Manage 7:141-144

Madsen JD (1998) Overview of the ecological assessment technology area. J Aquat Plant Manage 36:25-27

Madsen JD, Sartain B, Turnage G, Marko M (2016) Management of flowering rush in the Detroit Lakes, Minnesota. J Aquat Plant Manage 54:61-67
Mangan R, Baars JR (2013) Use of life table statistics and degree day values to predict the colonisation success of Hydrellia lagarosiphon Deeming (Diptera: Ephydridae), a leaf mining fly of Lagarosiphon major (Ridley) Moss (Hydrocharitaceae), in Ireland and the rest of Europe. Biol Control 64:143-151

Mataraza LK, Terrell JB, Munson AB, Canfield DE (1999) Changes in submersed macrophytes in relation to tidal storm surges. J Aquat Plant Manage 37:3-12

Mazzeo N, Rodriguez-Gallego L, Kruk C, Meerhoff M, Gorga J, Lacerot G, Quintans F, Loureiro M, Larrea D, Garcia-Rodriguez F (2003) Effects of Egeria densa Planch. beds on a shallow lake without piscivorous fish. Hydrobiologia 506:591-602

McKee D, Hatton K, Eaton JW, Atkinson D, Atherton A, Harvey I, Moss B (2002) Effects of simulated climate warming on macrophytes in freshwater microcosm communities. Aquat Bot 74:71-83

Michelan TS, Silveira MJ, Petsch DK, Pinha GD, Thomaz SM (2014) The invasive aquatic macrophyte Hydrilla verticillata facilitates the establishment of the invasive mussel Limnoperna fortunei in Neotropical reservoirs. J Limnol 73:598-602

Miranda LE, Hodges KB (2000) Role of aquatic vegetation coverage on hypoxia and sunfish abundance in bays of a eutrophic reservoir. Hydrobiologia 427:51-57

Moe TF, Brysting AK, Andersen T, Schneider SC, Kaste O, Hessen DO (2013) Nuisance growth of Juncus bulbosus: the roles of genetics and environmental drivers tested in a large-scale survey. Freshw Biol 58:114-127

Moss B, Stansfield J, Irvine K, Perrow M, Phillips G (1996) Progressive restoration of a shallow lake: a 12-year experiment in isolation, sediment removal and biomanipulation. J Appl Ecol 33:71-86

Murphy KJ (1988) Aquatic weed problems and their management-a review. 1. The worldwide scale of the aquatic weed problem. Crop Prot 7:232-248

Nakamura K, Kayaba Y, Nishihiro J, Takamura N (2008) Effects of submerged plants on water quality and biota in large-scale experimental ponds. Landsc Ecol Eng 4:1-9

Nawrocki JJ, Richardson RJ, Hoyle ST (2016) Monoecious hydrilla tuber dynamics following various management regimes on four North Carolina reservoirs. J Aquat Plant Manag 54:12-19

Nelson LS, Stewart AB, Getsinger KD (2002) Fluridone effects on fanwort and water marigold. J Aquat Plant Manage 40:58-63

Newman RM, Holmberg KL, Biesboer DD, Penner BG (1996) Effects of a potential biocontrol agent, Euhrychiopsis lecontei, on Eurasian watermilfoil in experimental tanks. Aquat Bot 53:131-150

Nichols SA (1991) The interaction between biology and the management of aquatic macrophytes. Aquat Bot 41:225-252

Nichols SA, Shaw BH (1986) Ecological life histories of the 3 aquatic nuisance plants, Myriophyllum spicatum, Potamogeton crispus and Elodea canadensis. Hydrobiologia 131:3-21

Noordhuis R, van der Molen DT, van den Berg MS (2002) Response of herbivorous water-birds to the return of Chara in Lake Veluwemeer, the Netherlands. Aquat Bot 72:349-367

O'Hare MT, Stillman RA, McDonnell J, Wood LR (2007) Effects of mute swan grazing on a keystone macrophyte. Freshw Biol 52:2463-2475

O’Sullivan C, Rounsefell B, Grinham A, Clarke W, Udy J (2010) Anaerobic digestion of harvested aquatic weeds: water hyacinth (Eichhornia crassipes), cabomba (Cabomba Caroliniana) and salvinia (Salvinia molesta). Ecol Eng 36:1459-1468

Perna CN, Cappo M, Pusey BJ, Burrows DW, Pearson RG (2012) Removal of aquatic weeds greatly enhances fish community richness and diversity: an example from the Burdekin river floodplain, tropical Australia. River Res Appl 28:1093-1104 
Perrow MR, Jowitt AJD, Stansfield JH, Phillips GL (1999) The practical importance of the interactions between fish, zooplankton and macrophytes in shallow lake restoration. Hydrobiologia 395:199-210

Peters J, Van Emmerik W (2013) Overdaad schaadt. Relatie waterplanten, vis en visserij complex. Visionair 30:17-19 (in Dutch)

Poirrier MA, Burt-Utley K, Utley JF, Spalding EA (2010) Submersed aquatic vegetation of the Jean Lafitte National Historical Park and Preserve. Southeast Nat 9:477-486

Pot R, ter Heerdt GNJ (2014) Succession dynamics of aquatic lake vegetation after restoration measures: increased stability after 6 years of development. Hydrobiologia 737:333-345

Quilliam RS, van Niekerk MA, Chadwick DR, Cross P, Hanley N, Jones DL, Vinten AJA, Willby N, Oliver DM (2015) Can macrophyte harvesting from eutrophic water close the loop on nutrient loss from agricultural land? J Env Man 152:210-217

Reeves JL, Lorchi PD, Kershner MW, Hilovsky MA (2008) Biol control of eurasian watermilfoil by Euhrychiopsis lecontei: assessing efficacy and timing of sampling. J Aquat Plant Manage 46:144-149

Richardson RJ (2008) Aquatic plant management and the impact of emerging herbicide resistance issues. Weed Technol 22:8-15

Richter D, Gross EM (2013) Chara can outcompete Myriophyllum under low phosphorus supply. Aquat Sci 75:457-467

Santos MJ, Khanna S, Hestir EL, Andrew ME, Rajapakse SS, Greenberg JA, Anderson LWJ, Ustin SL (2009) Use of hyperspectral remote sensing to evaluate efficacy of aquatic plant management. Invas Plant Sci Mana 2:216-229

Schneider SC, Moe TF, Hessen DO, Kaste O (2013) Juncus bulbosus nuisance growth in oligotrophic freshwater ecosystems: different triggers for the same phenomenon in rivers and lakes? Aquat Bot 104:15-24

Schoonbee HJ (1991) Biological-control of fennel-leaved pondweed, Potamogeton pectinatus (Potamogetonaceae), in South-Africa. Agr Ecosyst Environ 37:231-237

Schriver P, Bogestrand J, Jeppesen E, Sondergaard M (1995) Impact of submerged macrophytes on fish-zooplankton-phytoplankton interactions-large-scale enclosure experiments in a shallow eutrophic lake. Freshw Biol 33:255-270

Schwarz AM, Howard-Williams C (1993) Aquatic weed-bed structure and photosynthesis in 2 New-Zealand lakes. Aquat Bot 46:263-281

Sisneros D, Lichtwardt M, Greene T (1998) Low-dose metering of endothall for aquatic plant control in flowing water. J Aquat Plant Manage 36:69-72

Slade JG, Poovey AG, Getsinger KD (2008) Concentration-exposure time relationships for controlling sago pondweed (Stuckenia pectinata) with endothall. Weed Technol 22:146-150

Smith CS, Barko JW (1990) Ecology of eurasian watermilfoil. J Aquat Plant Manage 28:55-64

Søndergaard M, Moss B (1997) Impact of submerged macrophytes on phytoplankton in shallow freshwater lakes. In: Jeppesen E, Søndergaard M, Søndergaard M, Christoffersen K (eds) The structuring role of submerged macrophytes in lakes. Springer, New York, pp 115-132

Sondergaard M, Jeppesen E, Lauridsen TL, Skov C, Van Nes EH, Roijackers R, Lammens E, Portielje R (2007) Lake restoration: successes, failures and long-term effects. J Appl Ecol 44:1095-1105

Sondergaard M, Johansson LS, Lauridsen TL, Jorgensen TB, Liboriussen L, Jeppesen E (2010) Submerged macrophytes as indicators of the ecological quality of lakes. Freshw Biol 55:893-908

Spencer DF, Ksander GG (1999) Influence of dilute acetic acid treatments on survival of monoecious Hydrilla tubers in the Oregon House Canal, California. J Aquat Plant Manage 37:67-71

Spencer DF, Ksander GG, Donovan MJ, Liow PS, Chan WK, Greenfield BK, Shonkoff SB, Andrews SP (2006) Evaluation of waterhyacinth survival and growth in the Sacramento Delta, California, following cutting. J Aquat Plant Manage 44:50-60

Sprecher SL, Getsinger KD, Stewart AB (1998) Selective effects of aquatic herbicides on sago pondweed. J Aquat Plant Manage 36:64-68

Stallings KD, Seth-Carley D, Richardson RJ (2015) Management of aquatic vegetation in the southeastern United States. J Integr Pest Manag. doi:10.1093/jipm/pmv002

Suren AM (2009) Using macrophytes in urban stream rehabilitation: a cautionary tale. Restor Ecol 17:873-883

Tamayo M, Olden JD (2014) Forecasting the vulnerability of lakes to aquatic plant invasions. Invas Plant Sci Mana 7:32-45

Trebitz AS, Nichols SA, Carpenter SR, Lathrop RC (1993) Patterns of vegetation change in lake Wingra following a Myriophyllum spicatum decline. Aquat Bot 46:325-340

Van Donk E, van de Bund WJ (2002) Impact of submerged macrophytes including charophytes on phyto- and zooplankton communities: allelopathy versus other mechanisms. Aquat Bot 72:261-274

Van Nes EH, Scheffer M, van den Berg MS, Coops H (2002) Aquatic macrophytes: restore, eradicate or is there a compromise? Aquat Bot 72:387-403

Vereecken H, Baetens J, Viaene P, Mostaert F, Meire P (2006) Ecological management of aquatic plants: effects in lowland streams. Hydrobiologia 570:205-210

Verhofstad MJJM, Alirangues Núñez MM, Reichman EP, van Donk E, Lamers LPM, Bakker ES (2017) Mass development of monospecific submerged macrophyte vegetation after the restoration of shallow lakes: roles of light, sediment nutrient levels, and propagule density. Aquat Bot. 141:29-38. doi:10. 1016/j.aquabot.2017.04.004

Washington PM, Thomas GL, Marino DA (1992) Successes and failures of acoustics in the measurement of environmental impacts. Fish Res 14:239-250

WaterrecreatieAdvies (2005) Report: Onderzoek aantal recreatievaartuigen in Nederland. (in Dutch)

Wells RDS, Bannon HJ, Hicks BJ (2003) Control of macrophytes by grass carp (Ctenopharyngodon idella) in a Waikato drain, New Zealand. N Z J Mar Fresh 37:85-93

Wersal RM, Madsen JD (2011a) Comparative effects of water level variations on growth characteristics of Myriophyllum aquaticum. Weed Res 51:386-393

Wersal RM, Madsen JD (2011b) Influences of water column nutrient loading on growth characteristics of the invasive aquatic macrophyte Myriophyllum aquaticum (Vell.) Verdc. Hydrobiologia 665:93-105

Wilson CE, Darbyshire SJ, Jones R (2007) The biology of invasive alien plants in Canada. 7. Cabomba caroliniana A. Gray. Can J Plant Sci 87:615-638

Wingfield R, Murphy KJ, Gaywood M (2006) Assessing and predicting the success of Najas flexilis (Willd.) Rostk. and Schmidt, a rare European aquatic macrophyte, in relation to lake environmental conditions. Hydrobiologia 570:79-86

Wu MY, Wu J (2007) In-vitro investigations on ultrasonic control of water chestnut. J Aquat Plant Manage 45:76-83

Yakandawala K, Dissanayake D (2010) Mayaca fluviatilis Aubl.: an ornamental aquatic with invasive potential in Sri Lanka. Hydrobiologia 656:199-204

Yeo RR, McHenry WB (1977) Hydrilla, a new noxious aquatic weed in California. Calif Agr 31:4-5

Zefferman EP, Harris DJ (2016) Predicting drivers of nuisance macrophyte cover in a regulated California stream using boosted regression tree models. J Aquat Plant Manage 54:78-86

Zehnsdorf A, Hussner A, Eismann F, Roenicke H, Melzer A (2015) Management options of invasive Elodea nuttallii and Elodea canadensis. Limnologica 51:110-117 